\title{
Tracking the Limnoecological History of Lake Hiidenvesi (Southern Finland) Using the Paleolimnological Approach
}

\section{Luoto, Tomi P.}

2017-12

Luoto , T P , Rantala , M V \& Tammelin , M H 2017 , ' Tracking the Limnoecological History of Lake Hiidenvesi (Southern Finland) Using the Paleolimnological Approach ' , Water, Air and Soil Pollution , vol. 228 , no. 12 , 461 . https://doi.org/10.1007/s11270-017-3622-z

http://hdl.handle.net/10138/313028

https://doi.org/10.1007/s11270-017-3622-z

acceptedVersion

Downloaded from Helda, University of Helsinki institutional repository.

This is an electronic reprint of the original article.

This reprint may differ from the original in pagination and typographic detail.

Please cite the original version. 
1 Tracking the limnoecological history of Lake Hiidenvesi (southern Finland)

2 using the paleolimnological approach

3

4 Tomi P. Luoto ${ }^{1, *}$, Marttiina V. Rantala ${ }^{2}$ \& Mira H. Tammelin ${ }^{3}$

5

$6 \quad{ }^{1}$ Department of Environmental Sciences, University of Helsinki

$7 \quad$ Niemenkatu 73, 15140 Lahti, Finland

8

$9 \quad{ }^{2}$ Department of Geosciences and Geography, University of Helsinki

P.O. Box 64, 00014 University of Helsinki, Finland

11

${ }^{3}$ Department of Geography and Geology, University of Turku

20014 University of Turku, Finland

*Corresponding author (tomi.luoto@helsinki.fi)

ORCID ID: 0000-0001-6925-3688

Acknowledgements

21

Funding for this research was provided by the Hiidenvesi Restoration Project, the Emil Aaltonen Foundation (grants\# 160156, 170161) and the Doctoral Program in Geosciences of the University of Helsinki. We are grateful for the two journal reviewers for constructive criticism that helped to 25 improve the manuscript. 
8

\section{Abstract}

We examined a sediment record from Lake Hiidenvesi in southern Finland using paleolimnological methods to trace its limnoecological history. In our record, beginning from the 1940's, chironomid (Diptera) assemblages shifted from typical boreal taxa towards mesotrophic community assemblages at $~ 1960-1980$ CE being finally replaced by eutrophic taxa from the 1990's onward. The diatom (Bacillariophyceae) assemblages reflected relatively nutrient rich conditions throughout the record showing a further increase in eutrophic taxa from the 1970's onward. A chironomidbased reconstruction of late-winter hypolimnetic dissolved oxygen (DO) conditions suggested anoxic conditions already in the 1950 's, probably reflecting increased inlake production due to allochthonous nutrient inputs and related increase in biological oxygen consumption. However, the reconstruction also indicated large variability in long-term oxygen conditions that appear typical for the basin. With regard to nutrient status, chironomid- and diatom-based reconstructions of total phosphorus (TP) showed a similar trend throughout the record, although, chironomids indicated a more straightforward eutrophication process in the benthic habitat and seemed to reflect the intensified human activities in the catchment more strongly than diatoms. The DO and TP reconstructions were mostly similar in trends compared to the measured data available since the 1970's/1980's. However, the increase in TP during the most recent years in both reconstructions was not visible in the monitored data. The results of our multiproxy study emphasize the significance of including both epilimnetic and hypolimnetic systems in water quality assessments and provide important long-term limnoecological information that will be useful in the future when setting targets for restoration.

Keywords: Chaoborus; chironomids; diatoms; hypolimnetic oxygen; nutrient enrichment; phosphorus 
Introduction

Assessments of long-term limnoecological dynamics extending beyond the observational period are essential for the successful implementation of lake management acts. Paleolimnology examines the environmental history of lakes and their catchments using sedimentary archives that preserve physical, chemical, and biological proxy information (Smol 2009). Paleolimnology has proven to be very useful in assessments of limnological reference conditions that allow the evaluation of natural dynamics, timing of change, and targets of restoration (Bennion et al. 2011). The most common biological proxy sources in assessments of reference state include diatom (Bacillariophyceae) algae and chironomid (Diptera: Chironomidae) insect larvae, of which remains preserve well in sediments and are identifiable to species or generic level (Dixit et al. 1992; Hofmann 1988). Diatoms and their fossil communities often readily reflect the nutrient development of the water column (Anderson 1997; Kauppila and Valpola 2003), whereas fossil chironomid midge assemblages tend to reflect changes in the bottom water, such as in the hypolimnetic oxygen concentrations (Brodersen and Quinlan 2006; Francis 2001) or deep-water nutrients (Vanni 2002).

In addition to ecological dynamics, fossil communities can be used to quantitatively reconstruct changes in limnology via the calibration set approach. In such reconstructions, the modern species optima in a training set are utilized in a sediment downcore using a transfer function, which connects the modern species optima with the past fossil communities producing a quantitative reconstruction of a particular variable. Diatoms are commonly used to quantitatively reconstruct long-term changes in total phosphorus (TP) (Kauppila et al. 2002) and pH (Battarbee et al. 2010), whereas chironomids are often used to reconstruct TP (Brooks et al. 2001) and hypolimnetic dissolved oxygen (DO) (Quinlan and Smol 2001). It is also possible to estimate the 
5

concentration of deep-water oxygen by using the ratio between chaoborids (Diptera: Chaoboridae) and chironomids as an indicator of anoxia (Quinlan and Smol 2010).

Our study site, Hiidenvesi, is a naturally clay-turbid and currently eutrophic lake in southern Finland. A recently initiated Hiidenvesi restoration project (2016-2021) aims to reduce the load of suspended solids and nutrients as well as to promote conditions for recreation. The longterm objective for the restoration work is to improve the ecological state of Hiidenvesi and diminish the signs of eutrophication. Lake restoration activities, such as the management of fish stock and the establishment of sedimentation basins in the catchment, have been performed since 1995 (Repka 2005), albeit without consistent effectiveness monitoring.

In this study, we examine the long-term ecological and limnological development of the lake using fossil diatom and chironomid analyses combined with quantitative paleolimnological modeling. The objective is to reconstruct changes in the planktonic and benthic communities and in the surface-water nutrient and deep-water oxygen levels of the basin in high resolution since the initiation of intensified human activity around the lake at the turn of the 1950s'. This knowledge will be useful when setting targets for lake restoration, especially in the case of reducing surface water nutrients and in evaluating the usefulness of artificial bottom-water oxygenation. The results of this study will also improve understanding of lake development under increasing anthropogenic pressure.

\section{Materials and methods}

Study site

Hiidenvesi $\left(60^{\circ} 22^{\prime} \mathrm{N}, 23^{\circ} 11^{\prime} \mathrm{E} ; 32 \mathrm{~m}\right.$ a.s.1.) is a clay-turbid lake located in southern Finland (Fig. 1). It is one of the largest lakes in the area $\left(30 \mathrm{~km}^{2}\right)$, also having a wide catchment area $\left(935 \mathrm{~km}^{2}\right)$. The 
lake is located between the city of Lohja and municipality of Vihti and it drains southwest via the Vänteenjoki River into Lake Lohjanjärvi. Lake water quality varies notably between the basins of Hiidenvesi, in general, the larger basins having better limnological status than the small and shallow basins. The study site Kiihkelyksenselkä is the main basin of Hiidenvesi having a surface area of $10.5 \mathrm{~km}^{2}$ and a maximum depth of $33 \mathrm{~m}$. Adjacent to the metropolitan area of Helsinki, the lake provides significant ecosystem services. However, the lake suffers from serious nutrient loading derived from agriculture, forestry and other sources of diffuse loading. Currently, the autumnal epilimnetic TP varies in the Kiihkelyksenselkä basin between $\sim 30$ and $40 \mu \mathrm{g} 1^{-1}$, total nitrogen (TN) between 800 and $1400 \mu \mathrm{g}^{-1}$, chlorophyll-a between $\sim 10$ and $20 \mu \mathrm{gl}^{-1}$, pH between 7.0 and 7.8, and the hypolimnetic DO between $\sim 4$ and $6 \mathrm{mg} \mathrm{l}^{-1}$. Hypolimnetic DO measurements (minimum oxygen during late summer) from the examined Kiihkelyksenselkä basin are available since $1981 \mathrm{CE}$ and epilimnetic autumn TP since 1973 CE (Finnish Environment Institute).

\section{Sediments}

An 18-cm sediment profile was collected in June 2015 from the Kiihkelyksenselkä basin at a water depth of 14 m using a Limnos gravity corer (Kansanen et al. 1991). The sediments were subsampled in the field into small plastic bags at $1 \mathrm{~cm}$ intervals. The sediment profile consisted of generally homogenous grey-brown clayey gyttja (6-12\% organic matter, Mörner 1982) (Fig. 2). The samples were stored in a cold room $\left(+4{ }^{\circ} \mathrm{C}\right)$ for later preparation for the paleolimnological analyses. Loss on ignition (LOI) was used to assess the organic content of the sediments and was determined first to avoid degradation of organic material. For the LOI, samples were first dried at $105^{\circ} \mathrm{C}$ for $12 \mathrm{~h}$ and then ignited in an oven at $550{ }^{\circ} \mathrm{C}$ for $4 \mathrm{~h}$ (Heiri et al. 2001).

\section{Midge analysis}


126 Volumetric sediment samples of $5 \mathrm{~cm}^{3}$ were prepared using standard methodology for subfossil 127 chironomid analysis (Brooks et al. 2007). Sediments were sieved through a $100-\mu \mathrm{m}$ mesh and the 128 residue was examined in a Bogorov sorting tray under a binocular microscope for extraction of 129 subfossil head capsules using fine forceps. All specimens (typically the $4^{\text {th }}$ instar larvae) were 130 permanently mounted in Euparal ${ }^{\circledR}$ on microscope slides and identified under a light microscope at 131100 to 400-times magnification. A minimum count size of 50 individuals was set (Larocque 2001). 132 Chironomids were identified using Brooks et al. (2007). From the same samples, chaoborids and ceratopogonids (Diptera: Ceratopogonidae) were also identified based on Finnish fossil specimens (Luoto 2009; Luoto and Nevalainen 2009).

Diatom analysis

Samples for diatom analysis were prepared following standard procedures (Battarbee et al. 2001).

Organic matter was removed by oxidizing sediment samples with hydrogen peroxide solution (30\% $\left.\mathrm{H}_{2} \mathrm{O}_{2}\right)$, after which a few drops of hydrochloric acid $(37 \% \mathrm{HCl})$ were added to remove carbonate minerals. Coarse minerogenic matter was removed physically by swirling the sample solution in a beaker and decanting the diatom suspension. The remaining sample residue was checked for absence of diatom valves before disposal. Samples were dried on coverslips and mounted with Naphrax® (Brunel Microscopes Ltd, Wiltshire, U.K.). Diatoms were enumerated under a light microscope at $1000 \mathrm{x}$ magnification, setting the minimum counting sum at 300 diatom valves.

146 Taxonomic determination was mainly based on the flora of Krammer and Lange-Bertalot 147 (1986-1991), with nomenclature updated where relevant due to taxonomic refinements (Suppl. 1). 
151 Sample-specific diversity for midges and diatoms was calculated using the Hill's (1973) N2 index, which represents the effective number of occurrences. Principal components analysis (PCA) was used to detect the direction of the main midge and diatom community variance in ordination space. The PCAs were run using square-root transformed relative abundances. Subsequently, segmented regression analysis was used to identify statistically significant breakpoints in the PCA scores applying a minimum confidence level of $95 \%$. The selection of the best breakpoint and function type was based on maximizing the statistical coefficient of explanation, and performing tests of significance using the program SegReg (Oosterbaan 2011).

Past variability in minimum hypolimnetic DO (i.e. late-winter in the training set) was reconstructed using a 30-lake chironomid-based calibration model for southern Finland ranging from anoxic to hypersaturated sites (Luoto and Nevalainen 2011; Luoto and Salonen 2010). The weighted averaging partial least squares (WA-PLS) model using one WA-PLS component has a cross-validated (leave-one-out) coefficient of determination $\left(r_{\text {jack }}^{2}\right)$ of 0.72 and a root mean squared error of prediction (RMSEP) of $2.4 \mathrm{mg} \mathrm{l}^{-1}$. In addition to DO, chironomid assemblages were used to reconstruct past changes in TP. The TP model (Luoto 2011) uses 51 lakes across Finland ranging from oligotrophic to hypertrophic sites $\left(\mathrm{TP}=1.5-105 \mu \mathrm{g} \mathrm{1^{-1 }}\right)$. The chironomid-based autumnal epilimnetic TP inference model uses WA-PLS technique with four calibration regression components and it has an $r^{2}$ jack of 0.92 and RMSEP of $6.7 \mu \mathrm{g}^{-1}$. The diatom-based epilimnetic TP reconstructions used a 47-lake calibration set from eastern Finland covering a TP gradient of 7-122 $\mu \mathrm{g} 1^{-1}$. The two-component WA-PLS model with leave-one-out cross-validation has an $r^{2}$ jack of 0.82 and RMSEP of $0.15 \log \mu \mathrm{g} \mathrm{l}^{-1}$ (Tammelin and Kauppila 2015). All reconstructions were performed using the program C2 (Juggins, 2007). The reconstructions were validated for their reliability by comparing the reconstructed values against limnological measurements. LOESS smoothing was applied to standardize chronological differences between the reconstructed and measured values. 
Sediment dating

177

178 Chronological determinations were performed using ${ }^{210} \mathrm{~Pb}$ and ${ }^{137} \mathrm{Cs}$ analysis at the 179 Radiochronology Laboratory of the Centre for Northern Studies, Laval, Québec (Canada). The age180 depth model was established using a constant rate of unsupported ${ }^{210} \mathrm{~Pb}$ supply (CRS) model 181 (Appleby 2001). The ${ }^{210} \mathrm{~Pb}$ and ${ }^{137} \mathrm{Cs}$ concentrations remained low due to high sediment 182 accumulation rate, yet high enough for the construction of a tentative chronology (Fig. 3).

\section{Results}

According to the LOI analysis (Fig. 2), the sediment profile was mostly inorganic corresponding to clayey gyttja (5.8-9.1\% of organic matter). Between $17-13 \mathrm{~cm}$, the LOI varied between 7 and $9 \%$ followed by a decrease to the record minimum at $10 \mathrm{~cm}$. Thereafter, the LOI progressively increased showing the highest values at the topmost sediment layers.

Owing to the low ${ }^{210} \mathrm{~Pb}$ and ${ }^{137} \mathrm{Cs}$ concentrations, we were able to construct only a tentative age-depth model (Fig. 3). Based on the CRS model, the core extends $\sim 70$ years back in time representing a bottom age that dates to the late 1940's. However, as the model represents large estimation errors, the chronology should be considered with caution. Nonetheless, the initiation of the ${ }^{137} \mathrm{Cs}$ peak at $8 \mathrm{~cm}$ that corresponds to the Chernobyl accident in 1986 fits well with the ${ }^{210} \mathrm{~Pb}$ 195 chronology. In lakes in southern Finland, Chernobyl fallout typically marks the only clear ${ }^{137} \mathrm{Cs}$ 196 peak (Ojala et al. 2017), hence, suggesting that the age-depth model is realistic. Linear time-depth 197 relationship provides a high sediment accumulation rate of $2.5 \mathrm{~mm}$ per year, which explains the low $198 \quad{ }^{210} \mathrm{~Pb}$ and ${ }^{137} \mathrm{Cs}$ concentrations. 
The midge assemblages in the sediment core consisted mostly of chironomids and chaoborids (Fig. 4). A total of 29 chironomid taxa were identified from the samples. In general, the chironomid flux (head capsules per volumetric sample) increased towards the present. Of the nonchironomid midges, Chaoborus flavicans was abundant throughout the core, whereas Bezzia-type ceratopogonids occurred only in the surface sediment. Of the chironomids, Tanytarsus glabrescenstype was abundant in the lower part of the core ( 1945-1970 CE). Sergentia was common in the 1960's and 1970's, when also T. mendax-type had its maximum abundances. In the later part of the core, Procladius thrived from the 1990's until 2000, after which T. glabrescens-type again increased in abundance and Chironomus plumosus-type appeared in the record. Midge diversity, measured as $\mathrm{N} 2$, showed an increasing trend throughout the record with the highest diversity reached at the most recent sample (Fig. 4).

In all, 146 different diatom taxa from 32 genera were identified from the samples (Suppl. 1). Planktonic taxa dominated the diatom assemblages (Fig. 5), with high abundance of Aulacoseira granulata, A. ambigua, and A. subarctica. A. subarctica type II (lower mantle height/valve diameter ratio) was the most common taxon in the lower part of the sediment profile ( 1945-1985 CE) but began to decline thereafter, and was largely replaced by a more slender morphotype in the upper part of the core. A. ambigua, A. islandica, and Fragilaria crotonensis displayed a slight increase from the 1970's onwards, and Stephanodiscus medius and Asterionella formosa showed their highest abundances since the 1980's. The benthic community was rich in species but low in numbers, with species of Fragilaria sensu lato (e.g., Staurosirella pinnata, Pseudostaurosira brevistriata) as the most abundant. Planktonic diatom diversity was slightly elevated between the 1960's and $2000 \mathrm{CE}$, with the lowest diversity recorded in the most recent sample (Fig. 5). In the benthic community, diatom diversity declined gradually since the 1960's.

The midge PCA axis 1 scores (Fig. 6) were negative in the bottom and top parts of the sediment sequence and mostly positive in between. Highest axis 2 scores occurred around the 
1980's. The diatom PCA axis 1 scores (Fig. 6) remained negative until the 1980's but shifted thereafter into positive scores showing a clear directional succession. The highest diatom axis 1 score occurred in the surface sediment sample. According to the segmented regression analysis, a significant breakpoint in the midge PCA axis 1 scores occurred at 1963 CE and in the axis 2 scores at 1976 CE. No significant breakpoint was found in the diatom axis 1 scores but in the axis 2 scores a breakpoint occurred at $1991 \mathrm{CE}$.

The chironomid-based hypolimnetic DO reconstruction varied from anoxic to welloxygenated conditions (Fig. 7). The highest DO $\left(8.3 \mathrm{mg} \mathrm{l}^{-1}\right)$ was reached already at the lowermost sediments but the conditions turned into oxygen deficiency and anoxia during the 1950-60's. In the 1960's the oxygen conditions improved and remained elevated until the 1980's. In the 1990's the oxygen state again deteriorated with anoxia occurring in the first half of the 1990 's. The $21^{\text {st }}$ century was characterized by consecutive increases and decreases in hypolimnetic DO. When comparing the trends between the DO reconstruction and the measured DO since the 1980's (Fig. 7), they show rather similar features despite representing different seasons (late winter vs. late summer).

The chironomid-based reconstruction of TP (Fig. 8) showed a general development from oligo-mesotrophic conditions between 1945 and 1975 CE to mesotrophy between 1980 and 2010 CE, finally reaching eutrophy at the present. The diatom-TP inferences did not show a clear eutrophication process. Nevertheless, the trend is otherwise very similar to the chironomid-based reconstruction with elevated values in the oldest and most recent samples as well as during the 1980's. Despite the differences, there was a significant correlation $\left(R=0.55, r^{2}=0.30, p<0.019\right)$ between the chironomid- and diatom-based TP reconstructions. In comparison to the measured data available since the 1970's (Fig. 8), the chironomid- and diatom-based TP trends showed close correspondence, with the exception that the measured TP did not record a recent increase that was particularly clear in the chironomid-based reconstruction. 


\section{Discussion}

\section{Ecological dynamics}

The fossil chironomid assemblages (Fig. 4) in Hiidenvesi were rather typical for a clay-turbid nutrient-rich lake in the area (Luoto and Ojala 2014, 2017; Luoto and Raunio 2011; Salonen et al. 1993). In addition to chironomids, Chaoborus flavicans, which prefers turbid and productive lakes (Liljendahl-Nurminen et al. 2002), was common throughout the sediment profile. Subsequently, the chaoborus:chironomid-ratio, which indicates the presence of anoxia (Quinlan and Smol 2010), provided evidence that hypolimnetic oxygen deficiency has occurred in the basin since the 1940's. visual predation by fish and, when the night falls, it rises up the water column to feed on zooplankton (Liljendahl-Nurminen 2006).

The most distinct change in the chironomid communities was the increase in mesotrophic chironomid taxa, such as Procladius, Tanytarsus mendax-type and Sergentia, at the mid-part of the stratigraphy (1960-2000 CE). In the more recent period, the most significant change was the appearance of the typical eutrophy indicating species Chironomus plumosus-type (Kansanen 1985; Salonen et al. 1993), which also tolerates oxygen deficiency, into the stratigraphy in the 1990's. A distinct diversity threshold was also crossed in the midge communities during the 1990's displayed as a sudden increase in diversity (Fig. 4). This is a typical development in a eutrophication process, as the number of benthic invertebrate species increases alongside nutrient enrichment due to increased habitat availability (Wiederholm 1980). However, when lakes become hypertrophic and permanently anoxic, the diversity naturally decreases (Bryce and Hobart 1972). 
The diatom diversity showed a decrease in benthic diatom life forms and a simultaneous increase in the planktonic diversity since the 1970's (Fig. 5). This shift in the diatom communities could indicate increased turbidity in the water column related to increased phytoplankton production and sediment flux from the catchment, reducing light availability to benthic growth. Overall, the diatom communities (Fig. 5) of the basin have been dominated by planktonic taxa, which require water column turbulence to linger in the euphotic zone. The abundant Aulacoseira granulata and Aulacoseira ambigua are typical for eutrophic lakes (Lotter 2001; Meriläinen et al. 2003; Miettinen 2003), and Aulacoseira subarctica is commonly affiliated with mesotrophic waters (Gibson et al. 2003). The presence of eutrophic Stephanodiscaceae species (e.g. Cyclostephanos dubius) provides further indication for high productivity (Miettinen 2003; Punning et al. 2008), whereas the small fragilarioids of the benthic community tolerate unstable environmental conditions and reduced light availability (Anderson 2000; Luoto et al. 2012), hence reflecting the turbid waters of Hiidenvesi.

The changes related to the eutrophication process were relatively small in scale and less clear-cut in diatoms in comparison to the development in the chironomid communities. Unlike in a previous paleolimnological assessment from the shallow Kirkkojärvenselkä basin of Hiidenvesi (Weckström et al. 2011), we found no evidence of a recent increase in small-sized eutrophypreferring cyclotelloid species in the deeper Aulacoseira-dominated Kiihtelyksenselkä basin, most probably due to the differences in the depths of the basins and associated divergence in the physical characteristics of the water column. The success of planktonic diatom taxa is strongly dependent on changes in thermal stratification and mixing regimes that are tightly coupled to external nutrient 295 Aulacoseira taxa and low numbers of small cyclotelloids, such as Cyclotella stelligera, in the upper parts of the studied sediment profile hence suggests efficient convective mixing in the Kiihkelyksenselkä basin of Hiidenvesi over the past decades. 
According to the PCAs, it appears that chironomids have responded, in addition to the 317 be examined.

\section{Limnological development}


initiation of intensified farming (Hietala-Koivu 2002), had caused bottom water oxygen deficiency and anoxia due to the increased transport of nutrients and their effects on biological oxygen consumption following increased catchment erosion (forest clearance for cultivation). In conjunction with the present results, chironomid fauna in the very shallow Kirkkojärvenselkä basin, examined in a previous paleolimnological survey (Weckström et al. 2011), suggested deteriorated oxygen conditions since the 1950's. In agreement with the measured minimum DO, the reconstruction showed improved oxygen conditions in the basin during the 1980's that was followed by significant oscillations in the values from the 1990's onwards. Although the reconstructed and measured trends were similar, there were differences in the values. This is most likely due to seasonal differences, since the oxygen calibration model is based on late-winter measurements, whereas the instrumentally measured minimum DO at the basin occurs during the late-summer (August).

Both the reconstructed and observed conditions at the present $\left(\mathrm{O}_{2} \sim 6 \mathrm{mg} \mathrm{l}^{-1}\right)$ suggest that there has been improvement in the oxygen state since the poor conditions of the 1990's. The current oxygen concentrations are rather typical for a baseline condition of a clay-turbid lake with intermediate human influence in the catchment (Luoto and Nevalainen 2011). The overall large variability in DO throughout the record and the apparent lack of a connection with the variations in the pelagic nutrient concentrations underscores the importance of other environmental controls, such as yearly variation in water column mixing, on hypolimnetic oxygen status. The impacts of the ongoing climate change may also affect the oxygen state through increased catchment erosion, longer ice-free period and higher biological productivity. Generally, increased erosion and biological production may have a deteriorating, while the diminished ice-cover an improving impact on oxygen state (Adrian et al. 2009; Foley et al. 2012).

Although the chironomid- and diatom-based TP reconstructions had similar trends and the values showed significant correlation, the changes were larger in the chironomid record 
compared to diatoms (Fig. 8). Regardless that both calibration models are based on epilimnetic TP, the differences in the model outputs could be due to habitat characteristics, since as benthic invertebrates, chironomids utilize bottom water phosphorus for growth and development (Aagaard 1982). Typically, there is more phosphorus available at the hypolimnion compared to the epilimnion (Salonen et al. 1984), which could explain the higher values in the chironomid-based reconstruction in the most recent part of the record.

In contrast to the diatom-based epilimnetic TP values that indicate mesotrophy already during the 1940's, the chironomid-based TP reconstruction showed oligo-mesotrophic conditions and a slightly decreasing trend in the initial part of the record with minimum values in the mid 1970's. The minimum TP is also reflected in the measured data representing the water quality conditions of the basin in the summer of 1974 CE. During the 1980's the basin shifted to a mesotrophic state, however, with temporarily lower summer nutrient conditions during the early 1990's. According to the chironomid-based reconstruction, there has been a rapid recent increase towards more nutrient-rich conditions. Although visible also in the diatom-based reconstruction, this recent nutrient enrichment was not, however, seen in the measured data, probably owing to the fact that it represents a snapshot in time (single measurement) compared to the longer integrated period in the proxy-based data.

Microbial activity and degradation processes of settled material in upper sediment layers are typically more intensive in surface sediments that in deeper (historical) sediments (Wetzel 2001) that could potential influence paleolimnological interpretations. However, the sediment profile consisted of mostly inorganic homogenic material and no distinct difference was observed in the sediment quality that could indicate possible problems. Generally, the best means to verify paleolimnological reconstructions is to compare them against instrumental data (Battarbee et al. 2012). In our study, the reconstructions appear realistic, not only based on the trends but also according to the inferred values. For example, the chironomid-inferred DO for the surface sample 
was $5.7 \mathrm{mg} \mathrm{l}^{-1}$, whereas the measured was $5.5 \mathrm{mg} \mathrm{l}^{-1}$ fitting well within the models RMSEP. In the diatom-based TP reconstruction, the reconstructed value for the present was $33 \mu \mathrm{g} \mathrm{1^{-1 }}$, whereas the

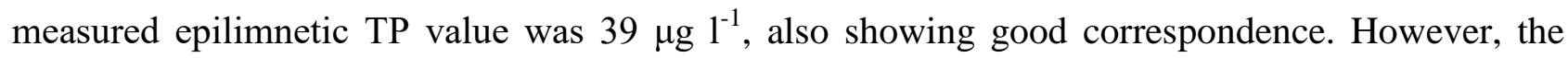
chironomid-based TP of $53 \mu \mathrm{g} \mathrm{l}^{-1}$ is closer to the modern measured hypolimnetic TP of $59 \mu \mathrm{g}^{-1}$ than the epilimnetic measurement, further suggesting that our interpretation on the influence of habitat characteristics on the inferences are correct. Although it is clear that chironomids and chaoborids respond to both nutrients and oxygen (Lencioni et al. 2008; Small et al. 2011), it can be spurious to simultaneously reconstruct both variables using the transfer function approach since it may not be clear how the chironomid-environment relationships change in time. In this study, the results demonstrate that both chironomid-based reconstructions were logical and realistic, at least during the observational period during which the instrumental verification of the reconstructions was possible.

\section{Conclusions}

The results of this paleolimnological study show consistent changes in the development of the nutrient and oxygen status of Hiidenvesi that were mostly comparable to the measured limnological data of the observational period. The lake benthos has changed since the 1940's first into a mesotrophic community in the 1960's and later in the 1990's into a eutrophic community. Similarly, the diatom communities show a clear directional shift with increases in the abundances of species typically related to the eutrophication process since the 1970's. In general, the basin appears to have remained relatively mildly nutrient stressed for a turbid lake in the early part of the record, although the diatom-based TP reconstruction suggested mesotrophic epilimnion already during the 1940's. From the end of the 1970's until the late 1980's and again since the mid-1990's the lake has developed into a more productive system, the most recent years reflecting a significant increase in 
nutrient conditions especially in the benthic habitat. The presence of Chaoborus throughout the record provides indications that a persistent low-oxygen refugia has prevailed in the hypolimnion. The chironomid-based reconstruction of hypolimnetic DO displayed cyclic fluctuations over the study period, largely irrespective of the nutrient development.

Although this study shows signs of recent eutrophication, it can also be seen from the results that, in comparison to a pristine boreal lake, the lake has been elevated in nutrients already since the beginning of the record at the 1940's. Similarly, it is also evidenced by the results that the basin has suffered from anoxia during the entire studied period. This research cannot define the actual reference state of the lake, since the record does not extend back in time before human disturbances in the ecosystem. The results of this study can, however, act as applicable guidelines for future preservation, conservation and restoration efforts following that the lake and catchment conditions during the 1940 's, prior to intensified farming, most probably represent a more realistic target state than conditions prior to any anthropogenic influence. This study also underlines the importance of separating the epilimnetic and hypolimnetic water bodies in long-term limnoecological assessments.

\section{References}

Aagaard, K. (1982). Profundal chironomid populations during a fertilization experiment in Langvatn, Norway. Ecography, 5, 325-331.

Adrian, R., O’Reilly, C.M., Zagarese, H., Baines, S.B., Hessen, D.O., Keller, W., Livingstone, D.M., Sommaruga, R., Straile, D., Van Donk, E., Weyhenmeyer, G.A., Winder, M. (2009). Lakes as sentinels of climate change. Limnology and Oceanography, 54, 2283-2297. 
Anderson, N.J. (2000). Miniview: Diatoms, temperature and climatic changes. European Journal of Phycology, 35, 307-314.

Anderson, N.J. (1997). Historical changes in epilimnetic phosphorus concentrations in six rural lakes in Northern Ireland. Freshwater Biology, 38, 427-440.

Appleby, P.G. (2001). Chronostratigraphic techniques in recent sediments. In: Last W.M., Smol J.P. (eds) Basin Analysis, Coring, and Chronological Techniques, Tracking Environmental Change Using Lake Sediments, vol. 1. Springer, Dordrecht, Netherlands, pp. 171-203.

Battarbee, R.W., Charles, D.F., Bigler, C., Cumming, B.F., Renberg, I. (2010). Diatoms as indicators of surface-water acidity. In: Smol, J.P. The Diatoms: Applications for the Environmental and Earth Sciences, 2nd Edition (Eds J.P. Smol \& E.F. Stoermer), 98-121. Cambridge University Press, Cambridge.

Battarbee, R.W., Anderson, N.J., Bennion, H., Simpson, G.L. (2012). Combining limnological and palaeolimnological data to disentangle the effects of nutrient pollution and climate change on lake ecosystems: problems and potential. Freshwater Biology, 57, 2091-2106.

Battarbee, R.W., Jones, V.J., Flower, R.J., Cameron, N.C., Bennion, H., Carvalho, L., Juggins, S. (2001). Diatoms. In: Smol, J.P., Birks, H.J.B., Last, W.M. (eds), Tracking Environmental Change Using Lake Sediments, Terrestrial, Algal, and Siliceous Indicators, vol. 3. Kluwer Academic Publishers, Dordrecht, Netherlands, pp. 155-202. 
447 Bennion, H., Battarbee, R.W., Sayer, C.D., Simpson, G.L., Davidson, T.A. (2011). Defining 448 reference conditions and restoration targets for lake ecosystems using palaeolimnology: a synthesis. 449 Journal of Paleolimnology, 45, 533-544.

450

451 Brodersen, K.P., Quinlan, R. (2006). Midges as palaeoindicators of lake productivity, 452 eutrophication and hypolimnetic oxygen. Quaternary Science Reviews, 25, 1995-2012. 453

454 Brodersen, K.P., Pedersen, O.L.E., Walker, I.R., Jensen, M.T. (2008). Respiration of midges 455 (Diptera; Chironomidae) in British Columbian lakes: oxy-regulation, temperature and their role as 456 palaeo-indicators. Freshwater Biology, 53, 593-602.

457

458 Brooks, S.J., Langdon, P.G., Heiri, O. (2007). The identification and use of Palaeoarctic 459 Chironomidae larvae in palaeoecology. QRA Technical Guide No. 10. Quaternary Research 460 Association, London.

Brooks, S.J., Bennion, H., Birks, H.J.B. (2001). Tracing lake trophic history with a chironomid-total 463 phosphorus inference model. Freshwater Biology, 46, 513-533.

464

Bryce, D., Hobart, A. (1972). The biology and identification of the larvae of the Chironomidae 467

Dixit, S.S., Smol, J.P., Kingston, J.C., Charles, D.F. (1992). Diatoms: powerful indicators of 469 environmental change. Environmental Science and Technology, 26, 22-33. 
471 Eggermont, H., Heiri, O. (2012). The chironomid-temperature relationship: expression in nature and 472 palaeoenvironmental implications. Biological Reviews, 87, 430-456.

473

474 Ekrem, T., Reiss, F., Langton, P.H. (1999). Tanytarsus mancospinosus sp. n.(Diptera, 475 Chironomidae) from eutrophic lakes in Europe. Norwegian Journal of Entomology, 46, 79-88.

477 Foley, B., Jones, I.D., Maberly, S.C., Rippey, B. (2012). Long-term changes in oxygen depletion in 478 a small temperate lake: effects of climate change and eutrophication. Freshwater Biology, 57, 278479289.

Francis, D.R. (2001). A record of hypolimnetic oxygen conditions in a temperate multi-depression lake from chemical evidence and chronomid remains. Journal of Paleolimnology, 25, 351-365.

483

Gibson, C.E., Anderson, N.J., Haworth, E.Y. (2003). Aulacoseira subarctica: taxonomy, physiology, ecology and palaeoecology. European Journal Phycology, 38, 83-101.

Heiri, O., Lotter, A.F., Lemcke, G. (2001). Loss on ignition as a method for estimating organic carbon content in sediments: reproducibility and comparability of results. Journal of

Hietala-Koivu, R. (2002). Landscape and modernizing agriculture: a case study of three areas in Finland in 1954-1998. Agriculture, Ecosystems and Environment, 91, 273-281. 
497 Hobbs, W.O., Hobbs, J.M.R., LaFrançois, T., Zimmer, K.D., Theissen, K.M., Edlund, M.B., 498 Michelutti, N., Butler, M.G., Hanson, M.A., Carlson, T.J. (2012). A 200-year perspective on 499 alternative stable state theory and lake management from a biomanipulated shallow lake. Ecological 500 Applications, 22, 1483-1496.

502 Hofmann, W. (1988). The significance of chironomid analysis (Insecta: Diptera) for 503 paleolimnological research. Palaeogeography, Palaeoclimatology, Palaeoecology, 62, 501-509.

504

Juggins, S. (2007). C2 Version 1.5 User Guide. Software for ecological and palaeoecological data analysis and visualisation. University of Newcastle, Newcastle upon Tyne.

Kansanen, P.H., Jaakkola, T., Kulmala, S., Suutarinen, R. (1991). Sedimentation and distribution of gamma-emitting radionuclides in bottom sediments of southern Lake Päijänne, Finland, after the Chernobyl accident. Hydrobiologia, 222, 121-140.

Kansanen, P.H. (1985). Assessment of pollution history from recent sediments in Lake Vanajavesi, southern Finland. II. Changes in the Chironomidae, Chaoboridae and Ceratopogonidae (Diptera) fauna. Annales Zoologici Fennici, 22, 57-90.

Kauppila, T., Moisio, T., Salonen, V.P. (2002). A diatom-based inference model for autumn epilimnetic total phosphorus concentration and its application to a presently eutrophic boreal lake.

Krammer, K., Lange-Bertalot, H. (1986). Bacillariophyceae. 1. Teil: Naviculaceae. In: Ettl, H., 
521 Gerloff, J., Heynig, H., Mollenhauer, D. (eds.), Süsswasserflora von Mitteleuropa. Band 2/1, 522 Gustav Fischer Verlag, Stuttgart, 875 pp.

523

524 Krammer, K., Lange-Bertalot, H. (1988). Bacillariophyceae. 2. Teil: Bacillariaceae,

525 Epithemiaceae, Surirellaceae. In: Ettl, H., Gerloff, J., Heynig, H., Mollenhauer. D. (eds.), 526 Süsswasserflora von Mitteleuropa. Band 2/2, Gustav Fischer Verlag, Stuttgart, 596 pp.

528 Krammer, K., Lange-Bertalot, H. (1991a). Bacillariophyceae. 3. Teil: Centrales, Fragilariaceae, 529 Eunotiaceae. In: Ettl, H., Gerloff, J., Heynig, H., Mollenhauer. D. (eds.), Süsswasserflora von 530 Mitteleuropa. Band 2/3, Gustav Fischer Verlag, Stuttgart, 576 pp.

532 Krammer, K., Lange-Bertalot, H. (1991b). Bacillariophyceae. 4. Teil: Achnanthaceae, Kritische 533 Ergänzungen zu Navicula (Lineolatae) und Gomphonema, Gesamtliteraturverzeichnis. In: Ettl, H., 534 Gärtner, G., Gerlof, J., Heynig, H., Mollenhauer. D. (eds.), Süsswasserflora von Mitteleuropa. Band 535 2/4, Gustav Fischer Verlag, Stuttgart, 437 pp.

537 Larocque, I. (2001). How many chironomid head capsules are enough? A statistical approach to 538 determine sample size for palaeoclimatic reconstructions. Palaeogeography, Palaeoclimatology, 539 Palaeoecology, 172, 133-142.

541 Lencioni, V., Bernabò, P., Vanin, S., Di Muro, P., Beltramini, M. (2008). Respiration rate and oxy542 regulatory capacity in cold stenothermal chironomids. Journal of Insect Physiology, 54, 1337-1342. 
Liljendahl-Nurminen, A. (2006). Invertebrate predation and trophic cascades in a pelagic food web 545 -the multiple roles of Chaoborus flavicans (Meigen) in a clay-turbid lake. $\mathrm{PhD}$ thesis, University of 546 Helsinki, s. 35.

Liljendahl-Nurminen, A., Horppila, J., Eloranta, P., Malinen T., Uusitalo, L. (2002). The seasonal 549 dynamics and distribution of Chaoborus flavicans larvae in adjacent lake basins of different 550 morphometry and degree of eutrohication. Freshwater Biology, 47, 1283-1295.

551

Lotter, A.F. (2001). The effect of eutrophication on diatom diversity: examples from six Swiss lakes. In: Jahn, R., Kociolek, J.P., Witkowski, A., Compére, P. (eds.), Lange-Bertalot-Festschrift, Studies on Diatoms. A.R.G. Gantner Verlag K.G. Ruggell, pp. 417-432.

555

Luoto, T.P. (2011). The relationship between water quality and chironomid distribution in Finland -

A new assemblage-based tool for assessments of long-term nutrient dynamics. Ecological Indicators, 11, 255-262.

Luoto, T.P. (2009). An assessment of lentic ceratopogonids, ephemeropterans, trichopterans and oribatid mites as indicators of past environmental change in Finland. Annales Zoologici Fennici, 46, 259-270.

Luoto, T.P., Nevalainen, L. (2011). Inferring reference conditions of hypolimnetic oxygen for 565 deteriorated Lake Mallusjärvi in the cultural landscape of Mallusjoki, southern Finland using fossil 566 midge assemblages. Water, Air, \& Soil Pollution, 217, 663-675. 
Luoto, T.P., Nevalainen, L. (2009). Larval chaoborid mandibles in surface sediments of small shallow lakes in Finland - implications for palaeolimnology. Hydrobiologia, 631, 185-195.

Luoto, T.P., Ojala, A.E.K. (2017). Meteorological validation of chironomids as a paleotemperature proxy using varved lake sediments. The Holocene, 27, 870-878.

Luoto, T.P., Ojala, A.E.K. (2014). Paleolimnological assessment of ecological integrity and eutrophication history for Lake Tiiläänjärvi (Askola, Finland). Journal of Paleolimnology, 51, 455468.

Luoto, T.P., Raunio, J. (2011). A comparison of chironomid-based total phosphorus training sets developed from contemporary pupal exuviae and sedimentary larval head capsules to infer lake trophic history. Fundamental and Applied Limnology, 179, 93-102.

Luoto, T.P., Salonen, V.-P. (2010). Fossil midge larvae (Diptera: Chironomidae) as quantitative indicators of late-winter hypolimnetic oxygen in southern Finland: a calibration model, case studies and potentialities. Boreal Environment Research, 15, 1-18.

Luoto, T.P., Nevalainen, L., Kauppila, T., Tammelin, M., Sarmaja-Korjonen, K. (2012). Diatominferred total phosphorus from dystrophic Lake Arapisto, Finland, in relation to Holocene paleoclimate. Quaternary Research, 78, 248-255.

Meriläinen, J.J., Hynynen, J., Palomäki, A., Mäntykoski, K., Witick, A. (2003). Environmental history of an urban lake: a palaeolimnological study of Lake Jyväsjärvi, Finland. Journal of Paleolimnology, 30, 387-406. 
594 Miettinen, J.O. (2003). A diatom-total phosphorus transfer function for freshwater lakes in 595 southeastern Finland, including cross-validation with independent test lakes. Boreal Environment 596 Research, 8, 215-228.

597

598 Mörner, N.A. (1982). Gyttja. In: Beaches and Coastal Geology, pp. 456-457. Springer US.

599

600 Ojala, A.E.K., Luoto, T.P., Virtasalo, J.J. (2017). Establishing a high-resolution surface sediment 601 chronology with multiple dating methods - Testing ${ }^{137}$ Cs determination with Nurmijärvi clastic602 biogenic varves. Quaternary Geochronology 37, 32-41.

603

604 Oosterbaan, R.J. (2011). SegReg: segmented linear regression with breakpoint and confidence 605 intervals.

606

607

Porter, S.D. (2008). Algal attributes: an autecological classification of algal taxa collected by the 609

610 Punning, J.-M., Kapanen, G., Hang, T., Davydova, N., Kangus, M. (2008). Changes in the water 611 level of Lake Peipsi and their reflection in a sediment core. Hydrobiologia, 599, 97-104.

613 Quinlan, R., Smol, J.P. (2010). Use of subfossil Chaoborus mandibles in models for inferring past 614 hypolimnetic oxygen. Journal of Paleolimnology, 44, 43-50.

615

616 Quinlan, R., Smol, J.P. (2001). Chironomid-based inference models for estimating end-of-summer 617 hypolimnetic oxygen from south-central Ontario shield lakes. Freshwater Biology, 46, 1529-1551. 
619 Repka, S. (2005). Lake Hiidenvesi - Studies on a clay-turbid and eutrophic multi-basin lake. 620 Advances in Limnology 59: 1-232.

621

622 Salonen, K., Jones, R.I., Arvola, L. (1984). Hypolimnetic phosphorus retrieval by diel vertical 623 migrations of lake phytoplankton. Freshwater Biology, 14, 431-438.

624

625 Salonen, V.P., Alhonen, P., Itkonen, A., Olander, H. (1993). The trophic history of Enäjärvi, SW 626 Finland, with special reference to its restoration problems. Hydrobiologia, 268, 147-162.

627

628 Small, G.E., Wares, J.P., Pringle, C.M. (2011). Differences in phosphorus demand among 629 detritivorous chironomid larvae reflect intraspecific adaptations to differences in food resource 630 stoichiometry across lowland tropical streams. Limnology and Oceanography, 56, 268-278.

631

632 Smol, J.P. (2009). Pollution of lakes and rivers: a paleoenvironmental perspective. John Wiley \& 633 Sons.

634

635 Tammelin, M., Kauppila, T. (2015). Iisalmen reitin luontainen rehevyys. Vesitalous, 2, 41-44. 636

637 Vanni, M.J. (2002). Nutrient cycling by animals in freshwater ecosystems. Annual Review of 638 Ecology and Systematics, 33, 341-370.

639

640 Weckström, J., Väliranta, M., Kaukolehto, M., Weckström, K. (2011). Kurkistus Hiidenveden 641 menneisyyteen - paleolimnologinen selvitys Kirkkojärveltä ja Mustionselältä. Länsi-Uudenmaan 642 vesi-ja ympäristö ry, Lohja. 
644 Wetzel, R.G. (2001). Limnology: lake and river ecosystems. Gulf Professional Publishing.

645

646

647

648

649

650

651

652

653

654

655

656 Figure captions

657

658 Fig. 1 Location of Lake Hiidenvesi in southern Finland and the sampling site at the 659 Kiihkelyksenselkä basin

660

661 Fig. 2 Lithology, water content and organic matter content (measured as loss on ignition) of the 662 sediment profile from Hiidenvesi

663

664 Fig. 3 Total specific activity of ${ }^{210} \mathrm{~Pb}$ and ${ }^{226} \mathrm{Ra}$ (daughters) and accumulation of ${ }^{137} \mathrm{Cs}$ in the 665 sediment core from Hiidenvesi. The age-depth model is based on constant rate of unsupported ${ }^{210} \mathrm{~Pb}$ 666 supply model (CRS). The peak in ${ }^{137} \mathrm{Cs}$ results from the Chernobyl accident fallout in 1986 667 
668 Fig. 4 Midge stratigraphy from Hiidenvesi including the absolute and relative abundances of 669 chironomids and chaoborids. The chaoborid:chironomid-ratio indicates severity of anoxia and N2 670 diversity index represents the effective number of occurrences

671

672 Fig. 5 Relative (\%) abundances of the most common ( $\max \geq 2 \%$ ) diatom taxa in the sediment 673 profile from Hiidenvesi. The N2 diversity index represents the effective number of occurrences

674

675 Fig. 6 Principal component analysis (PCA) plot for midge $\left(\lambda_{1}=0.23, \lambda_{2}=0.17\right)$ and diatom $\left(\lambda_{1}=0.28\right.$, $\left.676 \lambda_{2}=0.09\right)$ assemblages in the Hiidenvesi sediment record

677

678 Fig. 7 Chironomid-inferred hypolimnetic dissolved oxygen (DO) from the Hiidenvesi sediment 679 profile compared against measured DO since the 1980's. The trend lines use LOESS smoothing $680 \quad(\operatorname{span} 0.4)$

681

Fig. 8 Chironomid- and diatom-inferred total phosphorus (TP) from the Hiidenvesi sediment profile compared against measured TP since the 1970's. The trend lines use LOESS smoothing (span 0.4)

684

685

Electronic Supplementary Material

686

687 Suppl. 1 List of diatom species with their habitat preferences and occurrences in the Hiidenvesi 688 sediment core. Updates in nomenclature are primarily based on Porter (2008) 